\title{
IgM lambda cytoplasmic crystals in three cases of immunocytoma: a clinical, cytochemical, and ultrastructural study
}

\author{
W. W. FEREMANS, P. NEVE, AND M. CAUDRON \\ From the Laboratories of Electron Microscopy, Pathology, and Experimental Medicine, Departments of \\ Haematology and Medicine, Hôpital Saint-Pierre, Université Libre de Bruxelles, Brussels, Belgium
}

SUMMARY Endoplasmic reticulum-associated crystals were seen in $1-10 \%$ of the bone-marrowo lymphocytes and in the lymphocytes of the peripheral blood in three cases of immunocytoma. Theircrystalline nature and their location in the cisternae of the rough endoplasmic reticulum was proved 3 by ultrastructural study. IgM lambda in the crystals was demonstrated by fluorescent and peroxi-⿳亠丷厂巾 dase-labelled antibody methods. The crystals did not stain with the PAS reaction, suggesting that the immunoglobulin was not bound to a carbohydrate group. A defect in glucosyltransferase activity with failure to modify the immunoglobulins could explain the absence of the PAS reaction and the accumulation of immunoglobulin in crystalline form before reaching the Golgi region.

Three patients originally diagnosed as suffering from chronic lymphocytic leukaemia showed intracytoplasmic crystals in their lymphocytes. Inclusions of this type were first reported by Bessis (1951) in a case of chronic lymphocytic leukaemia. Bernard et al. (1959) observed these crystalline bodies with the electron microscope. The presence of gammaglobulins and absence of PAS staining were noted by Goldberg (1960) and De Man and Meiners (1962). Flandrin et al. (1971) and Hurez et al. (1972) found IgM lambda in similar crystals, using a fluorescent-labelled antibody method. Crystals containing IgA lambda were described by Cawley et al. (1973).

In none of the 15 cases reported so far were the lymphocytes normal (Bessis, 1951; Bernard et al., 1959; Goldberg, 1960; De Man and Meiners, 1962; Flandrin et al., 1971; Hurez et al., 1972; Cawley et al., 1973, 1976; Clark et al., 1973; Stefani et al., 1977). Inclusions of a different structure have been studied in leukaemic lymphocytes by ZuckerFranklin (1963), Nardo and Norton (1972), Anday et al. (1973), Lagios et al. (1974), Brunning et al. (1975), Cawley et al. (1975), and Stefani et al. (1977).

The peroxidase-labelled antibody method (Mason et al., 1969; Taylor and Burns, 1974; Garvin et al.,

Received for publication 1 September 1977
1976; Pinkus et al., 1977) used in this study with immunofluorescence and electron microscopy isō an original technique for the specific identification of the immunoglobulin in these crystalline inclusions. We have tried to fit our findings into the new: classification of malignant lymphomas by Lennert? et al. (1975).

Patients and methods

The relevant clinical and haematological findings ino the three cases studied are shown in Tables 1 and 2.

Normocytic anaemia in the patient in case 1 was due to bone marrow infiltration with central throm- $\sigma$ bopenia, whereas microcytic anaemia in the patient ${ }^{\circ}$ in case 2 was related to blood loss from a duodenal N ulcer. Later the latter patient had several incidentso of haemolysis with a direct positive Coombs test (IgG specificity). The serum immunoglobulin levels were low in all three patients and urine $\stackrel{5}{+}$ immunoelectrophoresis did not show any immuno- 0 globulin chain. All patients reacted to chlorambucilo treatment with regression of lymph node enlarge- $\mathbb{D}$ ment and of lymphocytosis. The haemolytic anaemia in case 2 was cured with prednisolone. The three $\frac{}{\sigma}$ patients were still alive 22,38 , and 40 months respectively after their illness was diagnosed. 
Table 1 Clinical findings in three cases of immunocytoma

\begin{tabular}{|c|c|c|c|c|c|c|c|}
\hline Case No. & Sex & Age $(Y r)$ & Peripheral lymph nodes & Hepatomegaly & Splenomegaly & $H b(g / d l)$ & $\begin{array}{l}\text { Platelets } \\
\left(\times 10^{\circ} / I\right)\end{array}$ \\
\hline $\begin{array}{l}1 \\
2 \\
3\end{array}$ & $\begin{array}{l}\mathbf{M} \\
\mathbf{M} \\
\mathbf{F}\end{array}$ & $\begin{array}{l}47 \\
61 \\
65\end{array}$ & $\begin{array}{l}+ \\
+ \\
+\end{array}$ & $\begin{array}{l}- \\
- \\
-\end{array}$ & $\begin{array}{l}+ \\
+ \\
+\end{array}$ & $\begin{array}{r}5 \cdot 8 \\
5 \cdot 8 \\
12 \cdot 4\end{array}$ & $\begin{array}{l}14 \cdot 2 \\
202 \\
206\end{array}$ \\
\hline
\end{tabular}

Table 2 Haematological findings in three cases of immunocytoma

\begin{tabular}{|c|c|c|c|c|c|c|c|c|}
\hline \multirow[t]{2}{*}{ Case No. } & \multirow{2}{*}{$\begin{array}{l}W B C \\
\left(\times 10^{\bullet} / L\right)\end{array}$} & \multicolumn{2}{|c|}{ Peripheral lymphocytosis } & \multirow{2}{*}{$\begin{array}{l}\text { Bone marrow } \\
\text { lymphocytosis }(\%)\end{array}$} & \multirow{2}{*}{$\begin{array}{l}I g G \\
(m g / 100 \mathrm{ml})\end{array}$} & \multirow{2}{*}{$\begin{array}{l}I g A \\
(m g / 100 m l)\end{array}$} & \multirow{2}{*}{$\begin{array}{l}I g M \\
(\mathrm{mg} / 100 \mathrm{ml})\end{array}$} & \multirow[t]{2}{*}{ Urine Ig } \\
\hline & & $\left(\times 10^{\circ} / l\right)$ & $(\%)$ & & & & & \\
\hline $\begin{array}{l}1 \\
2 \\
3\end{array}$ & $\begin{array}{r}13 \cdot 8 \\
100 \cdot 8 \\
33.5\end{array}$ & $\begin{array}{r}8.8 \\
98.8 \\
29.1\end{array}$ & $\begin{array}{l}63.8 \\
98 \\
86.9\end{array}$ & $\begin{array}{l}93 \cdot 8 \\
82 \cdot 2 \\
96 \cdot 2\end{array}$ & $\begin{array}{l}460 \\
700 \\
500\end{array}$ & $\begin{array}{r}85 \\
112 \\
65\end{array}$ & $\begin{array}{l}85 \\
72 \\
30\end{array}$ & - \\
\hline
\end{tabular}

LIGHT MICROSCOPY

Blood and bone-marrow smears were treated with May-Grünwald-Giemsa, PAS staining according to Hayhoe and Flemans (1969), methylgreen-pyronine (Bessis, 1972), and orange acridine (Forteza, 1964).

\section{IMMUNOPEROXIDASE AND IMMUNO-}

FLUORESCENCE TECHNIQUES

The smears were fixed for five minutes in absolute ethanol and rinsed in $0.15 \mathrm{M} \mathrm{pH} \mathrm{7.4} \mathrm{phosphate}$ buffer at room temperature. The Dako rabbit antihuman immunosera IgA, IgM, IgG, kappa, and lambda were used first at a dilution of $1 / 40$ at $37^{\circ} \mathrm{C}$. Next the swine antirabbit immunoserum conjugated with horseradish peroxidase was used at $1 / 10$ dilution. The peroxidase was processed with alpha-naphtholpyronine staining according to Lillie (1965). For the immunofluorescence (Pearse, 1960) the Dako rabbit antihuman fluorescein-conjugated antibodies $\operatorname{IgA}, \operatorname{IgM}, \operatorname{IgG}$, kappa, and lambda were used.

\section{TECHNIQUE FOR ELECTRON MICROSCOPY}

Bone marrow obtained by sternal puncture was immediately fixed for $\mathbf{3 0}$ minutes at room temperature in 4\% distilled glutaraldehyde (Sabatini et al., 1963) in 0.1 M phosphate buffer (Millonig, 1962). Next, the cells were rinsed in the same buffer and postfixed with $2 \%$ osmium tetroxide. Dehydratation took place in graded concentrations of ethanol with centrifugation for 10 minutes at $1000 \mathrm{rpm}$ at each step of the manipulation.

Finally, the material was embedded in Epon (Luft, 1961), sectioned with a Diatome diamond knife on a LKB Ultratome III microtome. Ultrathin sections were stained with uranyl acetate and lead and observed with a Siemens Elmiskop I electron microscope.

\section{Results}

\section{LIGHT AND FLUORESCENT MICROSCOPE} FINDINGS

The morphology was similar in each of the cases. The average diameter of the lymphocytes was $11.3 \mathrm{~m} \mu$. The nucleus showed a normal chromatin and often contained a nucleolus. With MayGrünwald-Giemsa stain a varying number of colourless crystals were visible in the basophilic cytoplasm of 1 to $10 \%$ of the lymphocytes (Fig. 1). They were PAS-negative, although this procedure showed glycogen inside the cytoplasm (becoming negative-stained after adding saliva amylase). The treatment with ribonuclease supressed the cytoplasmic pyroninophilic staining which did not involve the crystals. Only the crystalline bodies became fluorescent after treatment with immunosera anti-IgM and anti-lambda (Figs. 2, 3). Fluorescence remained negative after exposure to antisera anti-IgA, anti-IgG, anti-kappa and also after staining with orange acridine.

The processing of the exogenous peroxidase by the immunoperoxidase method confirmed the results obtained with immunofluorescence. The crystals appeared brownish (Fig. 4) for anti-IgM and antilambda.

\section{ULTRASTRUCTURAL FINDINGS}

The ultrastructural features were identified in the three cases. In case 1 similar anomalies were found in four different specimens of marrow obtained at four-month intervals.

Usually rounded cells (Fig. 5) sometimes had long, thin cytoplasmic protrusions. Nucleoli were often encountered. The cytoplasm contained numerous ribosomes and mitochondria and in some places the rough endoplasmic cisternae appeared annular. 


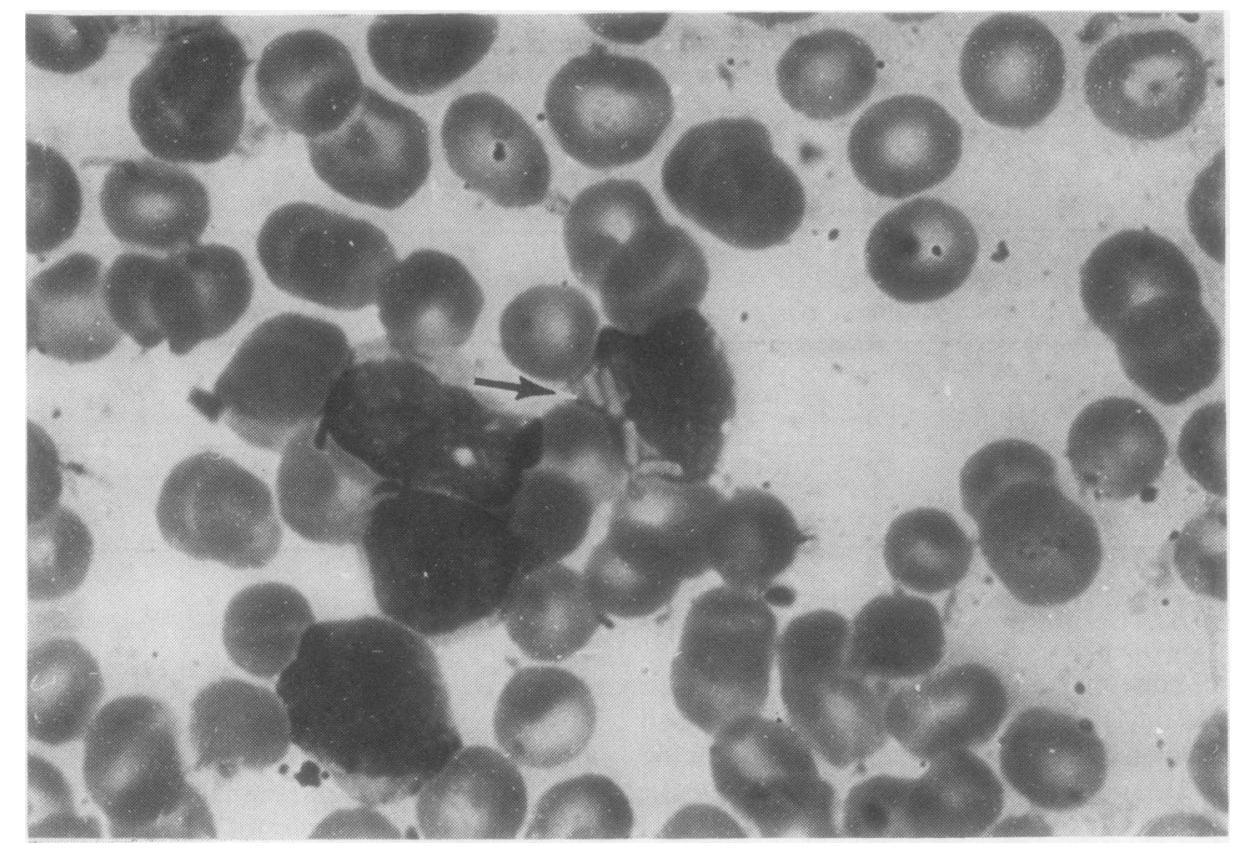

W. W. Feremans, P. Neve, and M. Caudron $\underset{\mathrm{T}}{\mathrm{J}}$

Fig. 1 May-Grünwald-Giemsa staining of lymphocyte with crystalline bodies (arrowed). $(\times 1300)$

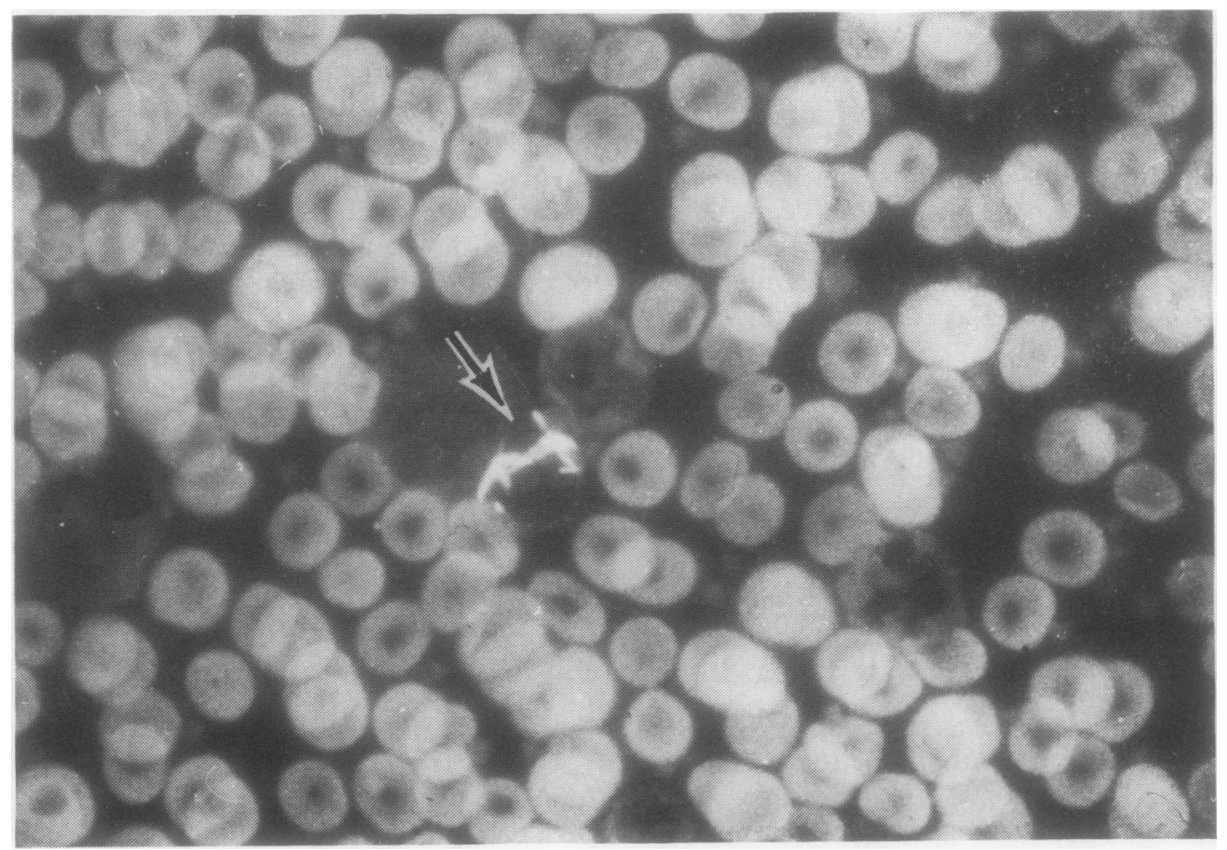

Fig. 2 Fluorescence of crystals with fluorescein-conjugated rabbit antihuman IgM serum (arrowed). $(\times 870)$ 


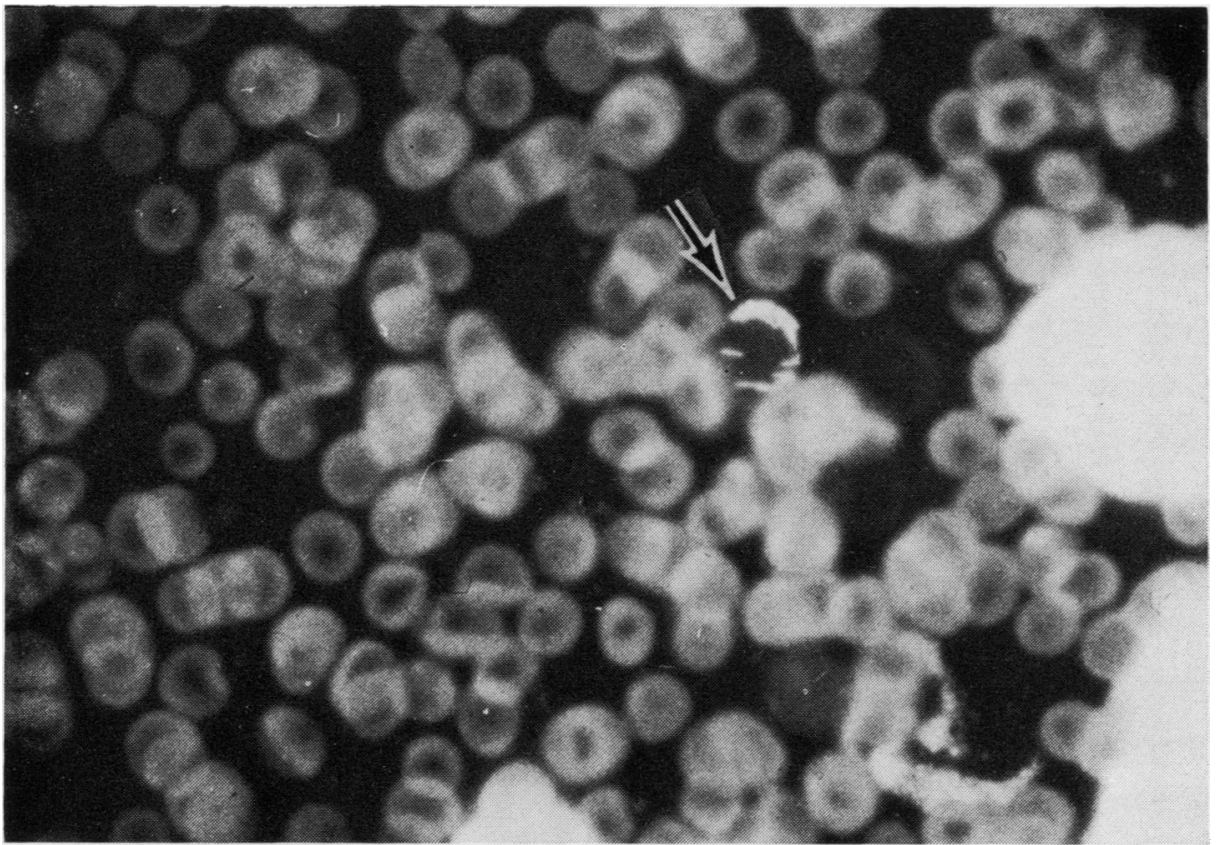

Fig. 3 Fluorescence of crystals with fluorescein-conjugated rabbit antihuman lambda serum (arrowed). $(\times 870)$

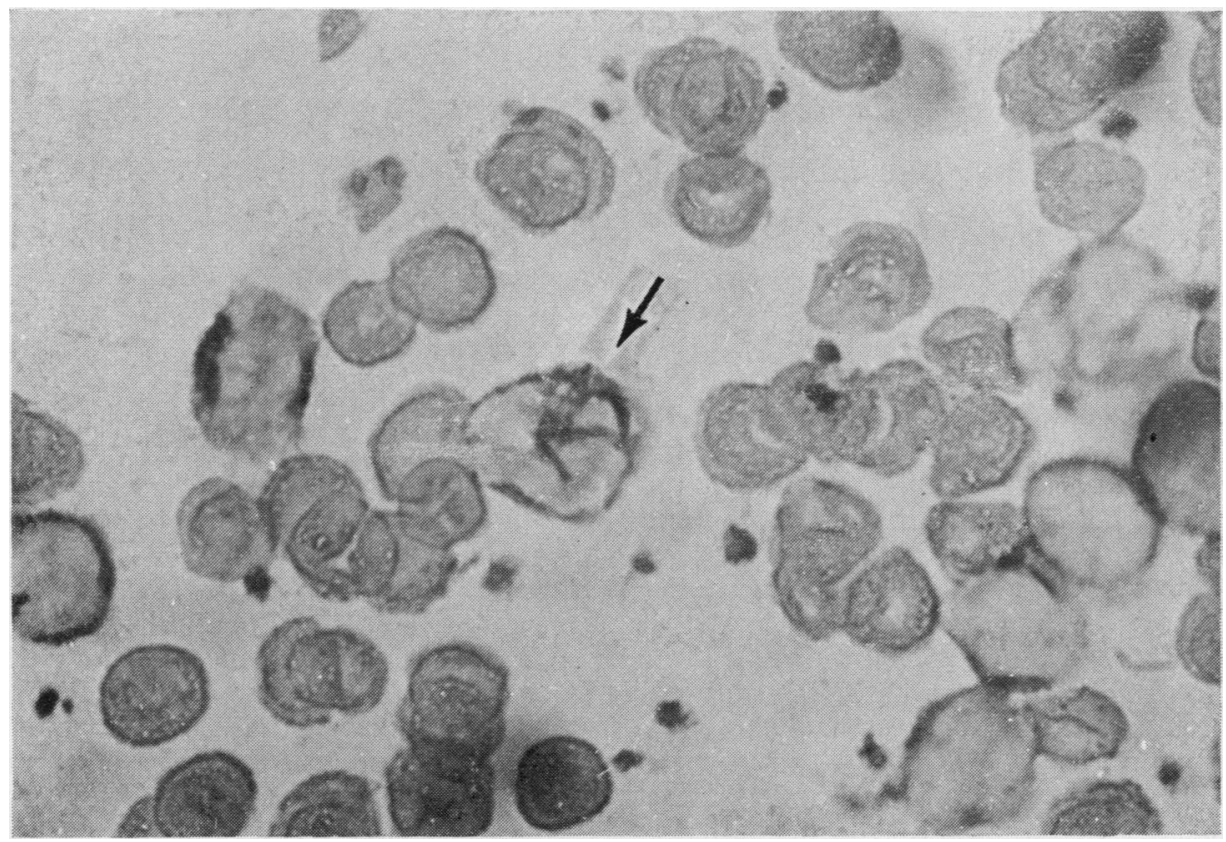

Fig. 4 Crystalline bodies coloured by the immunoperoxidase method (arrowed). $(\times 1300)$ 


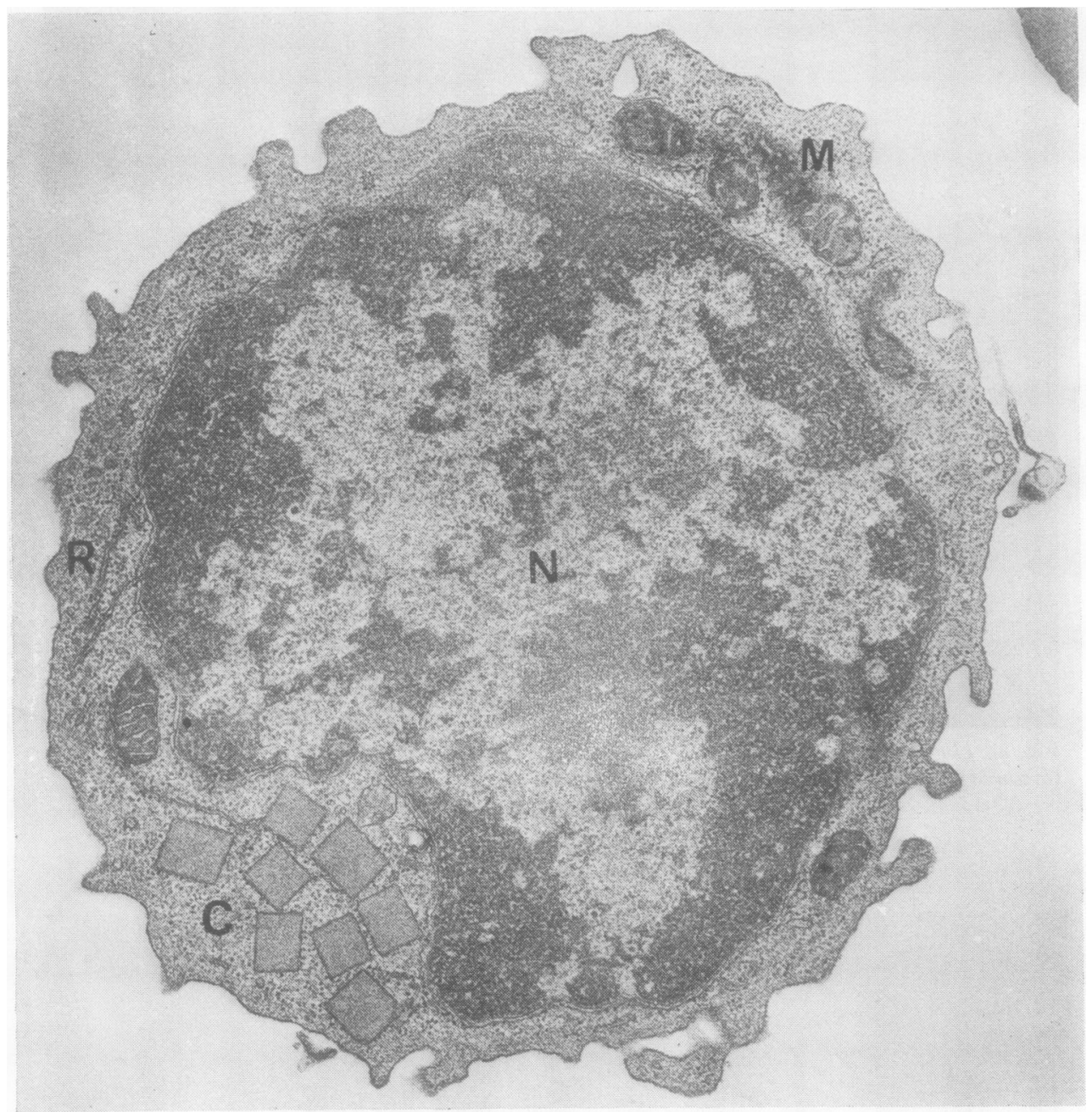

Fig. 5 Electron micrograph of lymphocyte with eight crystals. $C=$ crystals; $N=$ nuclear; $M=$ mitochondria; $R=$ rough endoplasmic reticulum. $(\times 24000)$

The Golgi apparatus did not seem to be very active. Some acanthosomes, microtubules, and multivesicular bodies were also seen (Fig. 6). The most important ultrastructural feature was the intracytoplasmic crystals, which were square in transverse section with a periodic structure and bordered by membranes of rough cytoplasmic reticulum (Figs. 7, 8). On longitudinal section the crystalline body had a rectangular or trapeze profile often with two open ends (Fig. 6). The periodic structure was then oriented parallel to the longitudinal axis of the crystal.

The number of crystals varied and could be eight on a cellular section. Moreover, lymphocytes in case 3 showed many centriolar complexes.

\section{Discussion}

According to the classification of Lennert et al. (1975) our three cases were 'immunocytomas' like the 15 analogous cases reported since 1950. This $\omega$ terminology, initially used by Heremans (1960) and? Hobbs (1971), refers to malignant lymphoma of low-grade malignancy. The clinical pattern is similar to chronic lymphocytic leukaemia but the lymphoid infiltration is characterised by signs of immuno- $T$ globulin synthesis. With light microscopy increased $\frac{0}{\oplus}$ protein synthesis is suggested by the basophily, $\stackrel{\Omega}{\Omega}$ distinct cytoplasmic coloration with methyl green- $\triangle$ pyronine, and the frequent occurrence of nucleoli. However, the common morphological peculiarity 8 


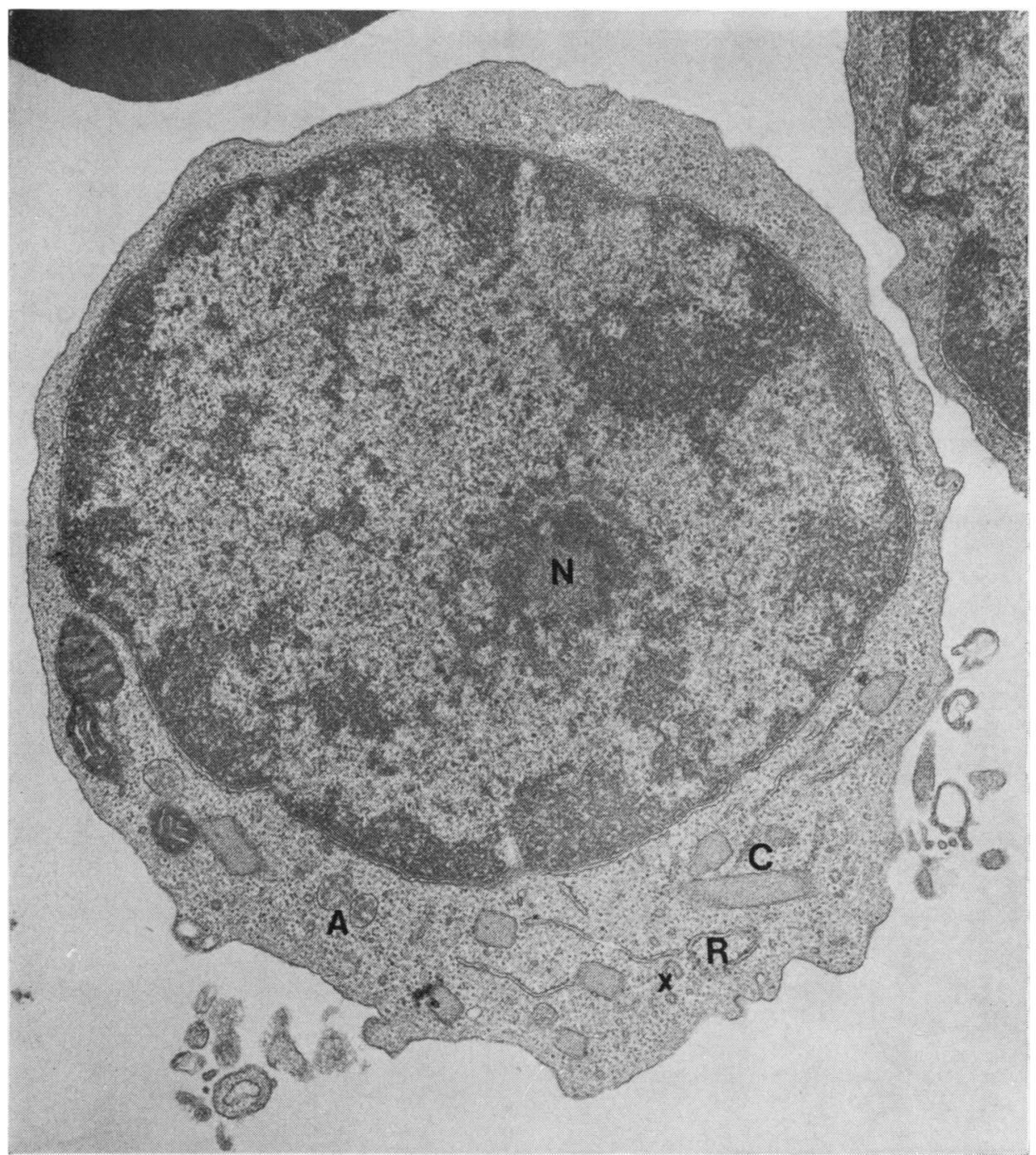

Fig. 6 Electron micrograph of a lymphocyte showing crystals $(C)$, multivesicular bodies $(A)$, annular cistern of rough endoplasmic reticulum $(R)$, acanthosomes $(X)$, nucleolus $(N) .(\times 20800)$

of these 18 cases is the presence of crystalline bodies whose periodic structure and the location inside the rough endoplasmic reticulum are demonstrated by transmission electron microscopy.

Cawley et al. (1976) have also observed such a crystal in the perinuclear cistern. Goldberg and Deane (1960) have demonstrated the presence of immunoglobulins inside those crystals by comparing the isoelectric point with a reference gamma-globulin. Until now immunoglobulin has been identified by immunofluorescence in 13 cases. IgM lambda was found in 11 and IgA lambda in two cases. One case with IgG kappa crystals has been reported but with a IgG kappa monoclonal seric peak (Preud'homme and Seligmann, 1972a).
The immunoperoxidase technique provided additional confirmation of the results obtained by immunofluorescence in our three cases. The prevalence of surface-bound monoclonal IgM in the other immunoglobulin classes is well established in chronic lymphocytic leukaemia and other B-lymphomas. However, it is more difficult to demonstrate the IgM in the cytoplasm of the B-lymphocytes with the immunofluorescence method (Brouet and Seligmann, 1977: Preud'Homme and Seligmann, 1972b). The nature of the defect in the leukaemic lymphocytes leading to intracytoplasmic accumulation of immunoglobulin crystals remains hypothetical.

A lack of balance between immunoglobulin synthesis and secretions might be considered. 


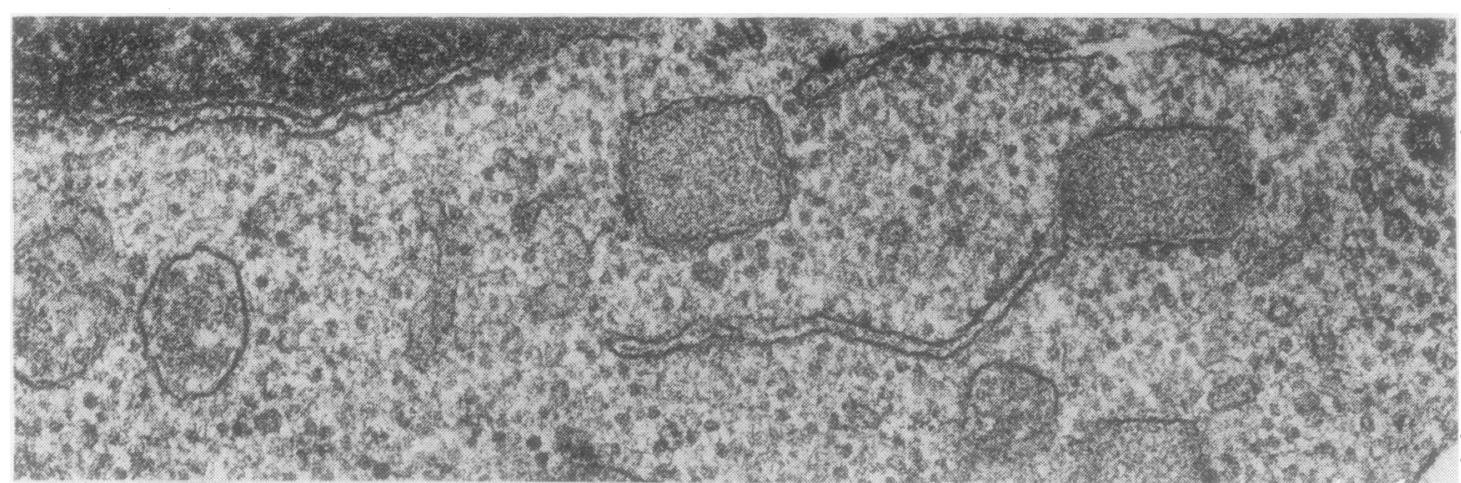

Fig. 7 High magnification electron micrograph of crystal inside rough endoplasmic cistern. $(\times 67000)$

Either synthesis is increased but secretion does not follow at the same rate or some delay in secretion occurs in the presence of a usual level of synthesis. There is no ultrastructural feature that points to increased protein production. Indeed, the ergastoplasm of the lymphocyte is less abundant than in the plasmocyte and there is no hypertrophy of the Golgi apparatus. Nevertheless, the accumulation of the crystals inside the rough endoplasmic reticulum might correspond to a block before the Golgi apparatus. The PAS-negative staining of the crystalline bodies (except for the case of Goldberg) suggests that these immunoglobulins are lacking their carbohydrate chain. This lack might perhaps $-{ }^{-}$ correspond to a defect at the level of the glycosyltransferases (Hurez et al., 1969; Sherr and Uhr, 1971; Schachter, 1974; Louisot et al., 1976).

The suggested form of the crystals is described bye 
De Man and Meiners (1962). The mechanism of the crystallization might be explained by a surpassing of the solubility process with modification of the tertiary structure of the immunoglobulin.

Flandrin et al. (1971) tended to suppose that the immunoglobulin release from the plasma membrane was impeded. Indeed, they found surface-bound immunoglobulins identical with those of the crystalline bodies. But these findings tend to be divergent. For example, Cawley et al. (1976) did not find an alpha heavy chain on the plasma membrane of cells that contain IgA lambda crystals, whereas they demonstrated the $\mu$ heavy chain in the cases with IgM lambda crystals. Moreover, only 1 to $2 \%$ of the circulating lymphocytes in cases 1 and 3 showed membrane-bound immunoglobulins by immunofluorescence (case 2 was not tested).

This work was supported by contract No. 3900175 of the Fonds de la recherche scientifique médicale. We thank Professor P. Dustin and Dr R. DenolinReubens for suggestions and criticism of the manuscript, Mrs R. Menu and Mr J. Hupin for technical assistance, and Messrs J. L. Conreur and R. Vienne for photographic work. We acknowledge the help of Dr P. Gausset, who did the research on the surface-bound immunoglobulins, Dr M. Prevot, who sent us the second case, and Mrs Vandenabeele for the typing.

\section{References}

Anday, G. J., Goodman, J. R., and Tishkoff, G. H. (1973). An unusual cytoplasmic ribosomal structure in pathologic lymphocytes. Blood, 41, 439-449.

Bernard, J., Bessis, M., Soulier, J. P., and Thiéry, J. P. (1959). Etude au microscope électronique d'une leucémie lymphoïde avec cristaux intra-cytoplasmiques. Revue d'Hématologie, 14, 227-237.

Bessis, M. (1951). Étude au microscope électronique des leucocytes normaux et leucémiques. Acta Unio Internationalis Coutra Canaam, 7, 646-659.

Bessis, M. (1972). Coloration de Unna-Pappenheim. In Cellules du Sang, Normal et Pathologique, pp. 31-32. Masson, Paris.

Brouet, J. C., and Seligmann, M. (1977). Chronic lymphocytic leukaemia as an immunoproliferative disorder. Clinics in Haematology, 6, 169-184.

Brunning, R. D., and Parkin, J. (1975). Ribosomelamella complexes in neoplastic hematopoietic cells. American Journal of Pathology, 79, 565-578.

Cawley, J. C., Barker, C. R., Britchford, R. D., and Smith, J. L. (1973). Intracellular IgA immunoglobulin crystals in chronic lymphocytic leukaemia. Clinical and Experimental Immunology, 13, 407-416.

Cawley, J. C., Emmines, J., Goldstone, A. H., Hamblin, T., Hough, D., and Smith, J. L. (1975). Distinctive cytoplasmic inclusions in chronic lymphocytic leuk- aemia. European Journal of Cancer, 11, 91-92.

Cawley, J. C., Smith, J., Goldstone, A. H., Emmines, J., Hamblin, J., and Hough, L. (1976). IgA and IgM cytoplastic inclusions in a series of cases of chronic lymphocytic leukaemia. Clinical and Experimental Immunology, 23, 78-82.

Clark, C., Rydell, .R. E., and Kaplan, M. E. (1973). Frequent association of IgM lambda with crystalline inclusions in chronic lymphatic leukemic lymphocytes. New England Journal of Medicine, 289, 113-117.

De Man, J. C. H., and Meiners, W. B. H. (1962). Crystals of protein nature in the cytoplasm of lymphatic cells in a case of lymphoreticular malignancy. Blood, 20, 492-500.

Flandrin, G., Hurez, D., Preud'Homme, J. L., Binet, J. L. L., and Seligmann, M. (1971). Leucémie lymphoïde chronique à cristaux avec macroglobuline monoclonale intracellulaire non excrétée. Nouvelle Revue Française d'Hématologie, 11, 422-428.

Forteza Bover, G. (1964). Atlas of Blood Cytology, p. 49. Toray, S. A., Barcelona. Grune and Stratton, New York.

Garvin, A. J., Spicer, S. S., and McKeever, P. E. (1976). The cytochemical demonstration of intracellular immunoglobulin in neoplasms of lymphoreticular tissue. American Journal of Pathology, 82, 457-478.

Goldberg, A. F. (1960). An unusual lymphomatous disease associated with intracytoplasmic crystals in lymphoplasmocytoid cells. Blood, 16, 1693-1707.

Goldberg, A. F., and Deane, H W (1960). A comparative study of some staining properties of crystals in a lympho-plasmocytoid cell, of Russell bodies in plasmocytes, and of amyloids with special emphasis on their isoelectric points. Blood, 16, 1708-1721.

Hayhoe, F. G. J., and Flemans, R. J. (1969). P.A.S. reaction (modified from McManus.) In An Atlas of Haematological Cytology, pp. 316-317. Wolfe Publishing, London.

Heremans, J. F. (1960). Les Globulines Sériques du Système Gamma. Arscia, Bruxelles.

Hobbs, J. R. (1971). Immunocytoma o'mice an' men. British Medical Journal, 2, 67-76.

Hurez, D., Preud'Homme, J. L., and Seligmann, M. (1969). Synthèse des immunoglobulines. Données récentes et intérêt en hématologie. Actualités Hématologiques, 3, 210.

Hurez, D., Flandrin, G., Preud'Homme, J. L., and Seligmann, M. (1972). Unreleased intracellular monoclonal macroglobulin in chronic lymphocytic leukaemia. Clinical and Experimental Immunology, 10, 223-224.

Lagios, M. D., Friedlander, L. M., Wallerstein, R. O., and Bohannon, R. A. (1974). Atypical azurophilic crystals in chronic lymphocytic leukaemia. American Journal of Clinical Pathology, 62, 342-349.

Lennert, K., Mohri, N., Stein, H., and Kaiserling, E. (1975). The histopathology of malignant lymphoma. British Journal of Haematology, 31 (supplement), 193-203.

Lillie, R. D. (1965). Histopathologic Technic and Practical Histochemistry, 3rd edition, p. 227. McGraw-Hill, New York. 
Louisot, P., Richard, M., and Gateau, O. (1976). Les glycosyltransferases: importance biologique et pathologique. Annales de Biologie Clinique, 34, 243-253.

Luft, J. H. (1961). Improvements in epoxy resin embedding methods. Journal of Biophysical and Biochemical Cytology, 9, 409-414.

Mason, T. E., Phifer, R. F., Spicer, S. S., Swallow, R. A., and Dreskin, R. B. (1969). An immunoglobulinenzyme bridge method for localizing tissue antigens. Journal of Histochemistry and Cytochemistry, 17, 563-569.

Millonig, G. (1962). Further observations on a phosphate buffer for osmium solutions. Proceedings of the Vth International Congress for Electron Microscopy, edited by S. S. Breese, Jr., p. 8. Academic Press, New York.

Nardo, J. M., and Norton, W. L. (1972). Chronic lymphocytosis with lymphocyte inclusions. Annals of Internal Medicine, 76, 265-268.

Pearse, A. G. E. (1960). Fluorescent antibody methods. In Histochemistry, Theoretical and Applied, p. 137. Churchill, London.

Pinkus, G. S., and Said, J. W. (1977). Specific identification of intracellular immunoglobulin in paraffin sections of multiple myeloma and macroglobulinemia using an immunoperoxidase technique. American Journal of Pathology, 87, 47-58.

Preud'Homme, J. L., and Seligmann, M. (1972a). Immunoglobulins on the surface of lymphoid cells in Waldenström's macroglobulinemia. Journal of Clinical Investigation, 51, 701-705.
Preud'Homme, J. L., and Seligmann, M. (1972b). Surface bound immunoglobulins as a cell marker in $\underline{-}$ human lymphoproliferative diseases. Blood, 40, 777-794.

Sabatini, D. D., Bensch, K., and Barrnett, R. J. (1963). Cytochemistry and electron microscopy. The preserva-등 tion of cellular ultrastructure and enzymatic activity by aldehyde fixation. Journal of Cell Biology, 17, 19-58.

Schachter, H. (1974). Glycosylation of glycoproteins during intracellular transport of secretory products. Advances in Cytopharmacology, 2, 207-218.

Sherr, C. J., and Uhr, J. W. (1971). Immunoglobulin synthesis and secretion. VI. Synthesis and intracellularo transport of immunoglobulin in nonsecretory lymphoma cells. Journal of Experimental Medicine, 133, 901-920.

Stefani, S., Chandra, S., Schrek, R., Tonaki, H., and $\dot{\omega}$ Knospe, W. H. (1977). Endoplasmic reticulumassociated structures in lymphocytes from patients with chronic lymphocytic leukemia. Blood, 50, 1,? 125-139.

Taylor, C. R., and Burns, J. (1974). The demonstration of plasma cells and other immunoglobulin-containing cells in formalin-fixed, paraffin-embedded tissues using 5 peroxidase labelled antibody. Journal of Clinicak Pathology, 27, 14-20.

Zucker-Franklin, D. (1963). Virus-like particles in the lymphocytes of a patient with chronic lymphocytico leukaemia. Blood, 21, 509-512. 